\title{
Utilization of natural dyes from Zingiber officinale leaves and Clitoria ternatea flowers to prepare new photosensitisers for dye-sensitised solar cells
}

\begin{abstract}
Chlorophyll and ternatin were extracted from Zingiber officinale leaves and Clitoria ternatea flowers respectively. These natural dyes were applied as sensitisers in TiO2-based dyesensitised solar cells (DSSCs). Among 10 different solvents, the ethanol extracts revealed the highest absorption spectra of natural dyes extracted from Z. officinale and C. ternatea. A major effect of temperature increase was the increased extraction yield. High chlorophyll and ternatin yields were obtained under extraction temperatures of $80^{\circ} \mathrm{C}$ and $70{ }^{\circ} \mathrm{C}$, respectively. A notable decrease in $\mathrm{C}$. ternatea dye concentration at temperatures $>70{ }^{\circ} \mathrm{C}$ was also observed. High dye concentrations were obtained using acidic extraction solutions, particularly those with a $\mathrm{pH}$ value of 4. Experimental results showed that the DSSC fabricated with chlorophyll extracted from Z. officinale leaves exhibited a conversion efficiency of $0.30 \%$, open-circuit voltage (Voc) of $0.56 \mathrm{~V}$, short-circuit current (Isc) of 0.8 $\mathrm{mA} / \mathrm{cm}-2$ and fill factor (FF) of $57.93 \%$. The DSSC sensitized with ternatin from C. ternatea flowers displayed a conversion efficiency of $0.13 \%$, Voc of $0.54 \mathrm{~V}$, Isc of $0.3 \mathrm{~mA} / \mathrm{cm}^{-2}$ and FF of $81.82 \%$.
\end{abstract}

Keyword: DSSC; Zingiber officinale; Clitoria ternatea; Natural dyes; Chlorophyll; Ternatin 